\title{
Article \\ Effect of Blood Circulation in the Upper Limb after Flossing Strategy
}

\author{
Dagmar Pavlů $^{1, * \mathbb{C}}$, David Pánek ${ }^{1}$, Eliška Kuncová ${ }^{1}$ and Jin Seng Thung ${ }^{2} \mathbb{C}$ \\ 1 Faculty of Physical Education and Sport, Charles University, 16252 Prague, Czech Republic; \\ panek@ftvs.cuni.cz (D.P.); k.elik@seznam.cz (E.K.) \\ 2 Translational Research Centre, Research and Innovation Division, National Sports Institute of Malaysia, \\ Kuala Lumpur 57000, Malaysia; jinseng@isn.gov.my \\ * Correspondence: pavlu@ftvs.cuni.cz; Tel.: +420-220-172-240
}

\section{check for}

updates

Citation: Pavlů, D.; Pánek, D.; Kuncová, E.; Thung, J.S. Effect of Blood Circulation in the Upper Limb after Flossing Strategy. Appl. Sci. 2021, 11, 1634. https://doi.org/10.3390/ app11041634

Academic Editor: Gregory Barshtein

Received: 8 January 2021

Accepted: 8 February 2021

Published: 11 February 2021

Publisher's Note: MDPI stays neutral with regard to jurisdictional claims in published maps and institutional affiliations.

Copyright: (c) 2021 by the authors. Licensee MDPI, Basel, Switzerland. This article is an open access article distributed under the terms and conditions of the Creative Commons Attribution (CC BY) license (https:// creativecommons.org/licenses/by/ $4.0 /)$.

\begin{abstract}
A very popular method in the field of prevention, sports, and therapy is flossing, working with an elastic band. A number of effects have been reported with this approach, but there are so far only a few studies to objectivize the declared effects. The aim of our study was to determine the change in the blood supply to the musculus biceps brachii during and after the flossing method applied to the upper limb in the area of the shoulder joint. The study recruited 27 healthy respondents $(23.3 \pm 2.8$ years old). Measurement of the blood flow was performed on a Précisé 8008 (Ulrichstein, Germany) a device for measuring transcutaneous oxygen $\left(\mathrm{tcpO}_{2}\right)$ before, during the 2-min compression therapy applied in the area of the shoulder joint, and after. We noted that both upper limbs, the limb where the application was performed and the opposite limb reached significant changes in the blood flow in musculus biceps brachii. Due to the significant depression of perfusion after only 2 min of flossing, great caution is required when performing the flossing method. The "sponge effect," which means that after the occlusion is removed, the perfusion increases rapidly, was not confirmed by our study.
\end{abstract}

Keywords: flossing; blood circulation; musculus biceps brachii; transcutaneous oxygen

\section{Introduction}

In recent years, new approaches have emerged both in the field of physiotherapy and sport, which aim to influence the functional state of the patient and/or the athlete. One of the new trends of these times is flossing. This is a method that involves compression, which is achieved by using an elastic band. A number of effects have been reported with this approach, but there are so far only a few studies to objectivize the declared effects in blood circulation. In our paper, we, therefore, present a study that evaluates changes in blood flow in the muscle during the application of this approach and thus seeks to contribute to the objectivization and elucidation of the mode of action.

\subsection{Notes on the History and Terminology of Compression Therapy}

Compression therapy began to be used at the times of ancient Egyptian civilization [1]. Earlier, bandages were used mainly for open wound injuries, it was aimed to improve healing and prevent further damage to the injured tissues [2]. Ancient Romans also benefited from the effects of the bandage to eliminate the feeling of heavy legs after long standing [3]. At the beginning of the 20th century, the first mentions of vacuumcompression therapy appeared [4].

In 1960, a Japanese, Yoshiaki Sato, introduced training with bandaged limbs. At the end of the 1990s, compression therapy started to appear in sports as a regeneration and performance-enhancing technique. Various compression garments are developed for this purpose $[2,5]$. 


\subsection{The Flossing Method}

The compression technique known as flossing has only recently become one of the compression strategies and would be likely linked to the publication of Kelly Starrett and Glen Cordoza's book Becoming and Supple Leopard, published in 2014 [6]. In addition, we also recognize flossing in the field of dentistry or the neural flossing technique $[7,8]$. The compression technique of flossing, which is sometimes referred to as voodoo flossing or tissue flossing and uses short-term soft tissue compression $[9,10]$.

It uses an elastic rubber band to compress the tissue, which reduces the blood and lymphatic flow [11]. Literally, they are three basic principles that work around the flossing strategy. They are the so-called sponge effect, subcutaneous irritation, and kinetic resolve. The sponge effect consists of significantly reducing the blood flow by applying pressure to push blood and lymph out of the treated area. After the end of the application, a rapid return of blood to the tissue is expected. The principle of subcutaneous irritation utilizes the gate theory. It works on the principle of pain relief by increasing another afference, in this case, the pressure stimuli from the given area. Kinetic resolve works on the basis of mutual relaxation of skin, subcutaneous tissue, fascia, muscles, and tendons toward each other [11]. None of the above-mentioned effects have been objectively assessed, proven, or reported so far. In the literature reviews, we can currently detect the expected effects and modes of action of flossing. No studies are currently available to clarify or document specific principles of flossing.

The number of studies that have dealt with the flossing strategy is very small, and they mostly were evaluations of its effect on changes in the range of motions.

Williams et al. [12] compared the range of motion of the ankles of 16 probands. Plocker et al. [13] studied the effect of flossing on the range of motion in the shoulder joint and the strength of the upper limb. Hodeaux [14] also addressed the issue of the range of motion after flossing. Driller and Overmayer $[15,16]$ examined the effect of flossing on the range of motion of the ankle joint. Mills et al. [17] investigated the effect of flossing on the ankle joint in rugby players. Prill [10] focused on reducing the effort-induced muscle pain (delayed-onset muscle soreness (DOMS)) by flossing. Similarly, a number of new studies evaluated the effect of flossing on the range of motion [17-20].

If we look at studies dealing with perfusion changes in the application of flossing, we find only one. This study monitored only five subjects with the conclusion that the application of flossing did not affect tissue vascularization [21].

In the connection with recommendations of the flossing method, contraindications are also mentioned, but they are different in the available literature. There is uniformity among absolute contraindications of flossing, which include open wounds, skin symptoms or skin diseases, fractures, obstructive vascular diseases (e.g., thrombosis) and bacterial inflammation [11] arterial occlusive diseases, acute arthritis, malignant tumor disease, decompensated diabetes mellitus, chronic lymphedema of stage III, drugs that reduce blood clotting, Sudeck's syndrome, decompensated heart insufficiency [2] injuries at the site of application, and allergy to rubber; an alternative is an application through clothing [22].

\subsection{Application of Flossing Method}

Flossing should be applied for 1-3 min according to Ahlhorn et al. [11]. Kreutzer [22] states that the application should be stopped after approximately 2 min. Kruse [2] sets the application time to $2 \mathrm{~min}$ with a maximum of $3 \mathrm{~min}$. In case of whitening, intense stabbing pain, sensory disturbances, or patient discomfort, the tape should be removed immediately [11].

Compressive flossing tapes are made of natural rubber or latex and are available in various lengths, widths, and thicknesses. The rubber tape for flossing should be very flexible and should have good adhesion [2,11,22]. Wrapping should be done with a tension of $30-60 \%$, while the tension of $60 \%$ is used for large joints such as the knee. 
These recommendations, similarly to the most of considered results, are mostly based on practical experience. To date, there is no study that would support and/or objectivize the recommended practices.

\subsection{Objectives of the Study}

The aim of the present study was to determine the change in the blood supply to the musculus biceps brachii during and after compression therapy applied to the upper limb in the area of the shoulder joint by the flossing method.

\section{Materials and Methods}

\subsection{Subjects}

The study recruited 27 respondents (16 women and 11 men), deliberately selected healthy students (age $23.3 \pm 2.8$ years old; body height $1.74 \pm 0.09 \mathrm{~m}$; body mass $66.7 \pm 11.2 \mathrm{~kg}$; BMI $21.6 \pm 1.6)$. The basic condition for inclusion in the group was an absence of acute infection, physical activity on the day of measurement, and some of the stated contraindications for the flossing method. Probands, who were engaged only in common physical activities, including recreational sports, were selected for the study. No one was a top-level athlete.

All respondents were acquainted with the purpose of the examination, filled out the informed consent, and the experiment was approved by the Ethics Committee of Charles University, Faculty of Physical Education and Sport (EK UK FTVS No. 224/2018).

\subsection{Procedures}

Measurement of the blood flow to upper limbs was performed on a Précisé 8008 device (Medicap GmbH, Ulrichstein, Germany) - a device for measuring transcutaneous oxygen $\left(\mathrm{tcpO} \mathrm{O}_{2}\right)$.

In the initial position of sitting with the support of the back of the chair, legs supported by the soles on the floor and the upper limbs hanging down, electrodes of Précise 8008 were glued to the body. Two electrodes were always applied to musculus biceps brachii both on the right upper limb (RUL) and the left upper limb (LUL). A position in the medial line on the ventral side of the arm in the middle of the distance between the acromion and the medial epicondyle of the humerus was chosen to place the electrode on musculus biceps brachii.

After gluing the electrodes, recording of values on the Précisse 8008 device was started. After the values on the device were stabilized, application of the compression therapy by flossing on the right upper limb was started. RUL of the proband was passively lifted and laid on the therapist's shoulder. The start of the flossing tape (Lime Green; Sanctband Flossband) was applied at the point of attachment of musculus deltoideus and wound on the shoulder area with its winding inwards and with an overlap of individual turns by half of the width of the flossing tape. The application was performed with the same force by a trained and identical person. After winding the tape, the upper limb was returned to position along the body, where it remained for two minutes (Figure 1). After this time, the tape was removed from the proband's arm and the arm was returned to basal position, and after registering the elevation of blood flow rate, measurement continued for another $15 \mathrm{~min}$.

The transcutaneous oximetry method was used in the analysis. "Determination of transcutaneous oxygen tension $\left(\mathrm{tcpO}_{2}\right)$ is the method for testing peripheral skin perfusion at the capillary level based on measurement of the partial pressure of oxygen diffusing through skin" [23]. From the measured values it is possible to derive the absorption capacity of systems and the amount of dissolved oxygen in tissue, which informs us about the blood supply at the capillary level $[23,24]$. Transcutaneous monitoring measures the partial pressure on the skin surface, from which it is possible to infer the partial pressure of oxygen in arterial bed $\left(\mathrm{paO}_{2}\right)$. Thus, it is not a direct measurement of $\mathrm{paO}_{2}$, while the arterial pressure of oxygen is usually higher than the pressure measured transcutaneously. $\mathrm{TcpO}_{2}$ can be well used for long-term non-invasive monitoring of tissue perfusion [25]. 


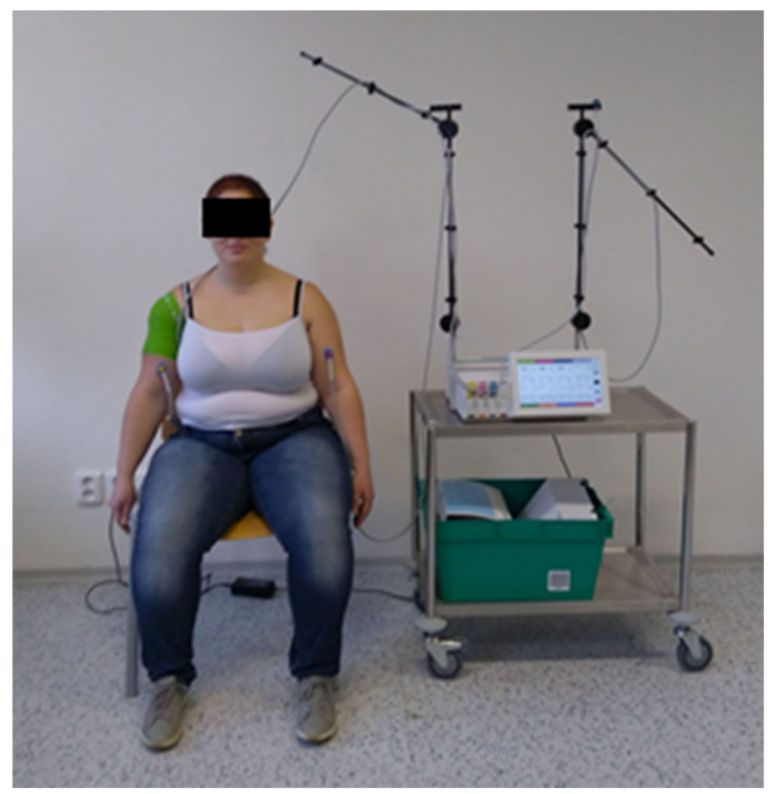

Figure 1. Position of the proband during the experiment-illustration photo.

The device uses a sensor working on the principle of fluorescence and does not require calibration before each measurement. It is able to record values of $0-2000 \mathrm{mmHg} \pm 10 \%$. The device achieves valid results when used in a room with a temperature of $15-35{ }^{\circ} \mathrm{C}$ and relative air humidity of $10-95 \%$. An advantage of this device is the adjustable sensor temperature to $40-44{ }^{\circ} \mathrm{C}$. For the purpose of this experiment, the temperature was set at $44{ }^{\circ} \mathrm{C}[24]$.

Using this method is safe. A contraindication to its use is only poor skin integrity and an allergy to the adhesive used material.

\subsection{Data Processing}

Data obtained during the measurement were evaluated by descriptive statistics. The change in values measured on the right upper limb (flossing application) and the left upper limb (without flossing application) was compared using a linear model and ANOVA testing. The linear model was chosen because it allows the use of more complex comparison of data with the expression of their interdependence. Comparison of the time of perfusion drop to the lowest level and the time of subsequent adjustment was performed using a paired $t$-test.

To evaluate the results, statistical data analysis was also used in the statistical program $\mathrm{R}$ ( $\mathrm{R}$ for Windows; GUI front-end), in the extension RStudio ( $\mathrm{R}$ for Windows; GUI front-end Ri386 3.6.1).

\section{Results}

The study yielded interesting results that do not fully correspond to the expected effects of the flossing method.

Figure 2 shows the changes in blood flow in the right, i.e., on the side of flossing application, and the left upper limb over time in one proband. There is an apparent significant depression of perfusion in the right upper limb during flossing and the subsequent normalization of the condition. In this case, there was an elevation of blood flow above the input value. This elevation, with the exception of two probands, was observed in all subjects tested. 
Table 1. Change in blood flow over time (T0-baseline, NN-lowest value, T2- after 2 min).

\begin{tabular}{|c|c|c|c|c|c|c|c|c|c|c|c|c|}
\hline \multicolumn{13}{|c|}{ Change in tcpO $\mathrm{O}_{2}(\mathrm{mmHg})$ over Time on na RUL a LUL } \\
\hline \multirow{2}{*}{ Proband } & \multicolumn{6}{|c|}{ RUL-Flossing Aplication (Time) } & \multicolumn{6}{|c|}{ LUL-without Aplication (Time) } \\
\hline & T0 & NN & T2 & T5 & T10 & T15 & DT0 & DNN & DT2 & DT5 & DT10 & DT15 \\
\hline 2 & 63 & 11 & 56 & 65 & 64 & 63 & 50 & 56 & 58 & 54 & 53 & 54 \\
\hline 3 & 70 & 18 & 61 & 79 & 88 & 88 & 82 & 80 & 84 & 87 & 91 & 93 \\
\hline 4 & 63 & 19 & 55 & 68 & NA & NA & 51 & 51 & 54 & 59 & 65 & 66 \\
\hline 5 & 50 & 10 & 48 & 67 & 73 & 73 & 52 & 55 & 55 & 59 & 62 & 61 \\
\hline 6 & 62 & 19 & 57 & 67 & 71 & 74 & 92 & 94 & 94 & 91 & 88 & 87 \\
\hline 7 & 63 & 12 & 32 & 33 & 43 & 61 & 53 & 55 & 39 & 32 & 40 & 57 \\
\hline 8 & 64 & 16 & 53 & 68 & 69 & 68 & 63 & 70 & 73 & 74 & 73 & 73 \\
\hline 9 & 64 & 19 & 53 & 71 & 77 & 79 & 84 & 81 & 84 & 86 & 91 & 91 \\
\hline 10 & 71 & 17 & 55 & 64 & 68 & 73 & 72 & 56 & 53 & 60 & 66 & 73 \\
\hline 11 & 64 & 21 & 53 & 67 & 75 & 76 & 59 & 65 & 68 & 71 & 71 & 71 \\
\hline 12 & 73 & 16 & 65 & 77 & 81 & 83 & 85 & 85 & 89 & 88 & 88 & 88 \\
\hline 13 & 76 & 16 & 63 & 82 & 83 & 86 & 77 & 75 & 77 & 77 & 76 & 76 \\
\hline 14 & 63 & 17 & 53 & 68 & 75 & 75 & 78 & 78 & 79 & 79 & 83 & 84 \\
\hline 15 & 90 & 23 & 65 & 85 & 92 & 89 & 84 & 88 & 89 & 87 & 89 & 87 \\
\hline 16 & 51 & 8 & 37 & 55 & 61 & 62 & 54 & 49 & 48 & 50 & 53 & 54 \\
\hline 17 & 44 & 6 & 16 & 32 & 33 & NA & 62 & 49 & 48 & 49 & 50 & NA \\
\hline 18 & 70 & 14 & 60 & 80 & 86 & 86 & 72 & 66 & 66 & 69 & 73 & 73 \\
\hline 19 & 58 & 9 & 44 & 60 & 65 & 66 & 54 & 48 & 49 & 52 & 58 & 59 \\
\hline 20 & 65 & 15 & 58 & 73 & 77 & 78 & 67 & 71 & 70 & 75 & 76 & 76 \\
\hline 21 & 65 & 16 & 54 & 67 & 68 & 72 & 78 & 82 & 81 & 82 & 81 & 84 \\
\hline 22 & 65 & 20 & 51 & 66 & 70 & 72 & 72 & 73 & 72 & 76 & 76 & 76 \\
\hline
\end{tabular}


Table 1. Cont.

\begin{tabular}{|c|c|c|c|c|c|c|c|c|c|c|c|c|}
\hline \multicolumn{13}{|c|}{ Change in tcpO $\mathrm{O}_{2}(\mathrm{mmHg})$ over Time on na RUL a LUL } \\
\hline \multirow{2}{*}{ Proband } & \multicolumn{6}{|c|}{ RUL-Flossing Aplication (Time) } & \multicolumn{6}{|c|}{ LUL-without Aplication (Time) } \\
\hline & T0 & $\mathbf{N N}$ & T2 & T5 & T10 & T15 & DT0 & DNN & DT2 & DT5 & DT10 & DT15 \\
\hline 24 & 51 & 9 & 45 & 60 & 59 & 56 & 60 & 63 & 64 & 64 & 64 & 63 \\
\hline 25 & 54 & 15 & 43 & 61 & 66 & 66 & NA & NA & NA & NA & NA & NA \\
\hline 26 & 68 & 16 & 59 & 68 & 72 & NA & 81 & 86 & 85 & 85 & 88 & NA \\
\hline 27 & 65 & 14 & 52 & 66 & 67 & 67 & 53 & 56 & 58 & 60 & 60 & 60 \\
\hline Diameter & 62.22222 & 14.81481 & 51.11111 & 65.2963 & 69.46154 & 72.375 & 66.53846 & 66.88462 & 67.53846 & 68.88462 & 70.88462 & 72.375 \\
\hline Median & 64 & 16 & 53 & 67 & 69.5 & 72.5 & 65 & 65.5 & 67.5 & 71 & 72 & 73 \\
\hline $\begin{array}{l}\text { Standard } \\
\text { deviation }\end{array}$ & 10.37566 & 4.154757 & 10.44681 & 11.96233 & 12.48455 & 9.227732 & 13.70915 & 14.05573 & 14.9852 & 14.86433 & 13.92929 & 12.07205 \\
\hline
\end{tabular}




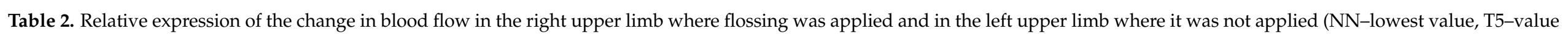
at $5 \mathrm{~min}, \mathrm{~T} 10-$ value at $10 \mathrm{~min}, \mathrm{~T} 15-$ value at $15 \mathrm{~min}$ ).

\begin{tabular}{|c|c|c|c|c|c|c|c|c|c|c|}
\hline \multirow{2}{*}{ Proband/Time } & \multicolumn{5}{|c|}{ RUL-Flossing Aplication (\%) } & \multicolumn{5}{|c|}{ LUL-without Aplication (\%) } \\
\hline & y_NN & $\mathbf{y}_{-} \mathrm{T} 2$ & $\mathrm{y}_{-} \mathrm{T} 5$ & $\mathrm{y}_{-} \mathrm{T} 10$ & $\mathrm{y}_{-} \mathrm{T15}$ & y_NN & $\mathrm{y}_{-} \mathrm{T} 2$ & y_T5 & $\mathbf{y}_{-} \mathbf{T} 10$ & y_T15 \\
\hline 1 & 0.240 & 0.960 & 1.240 & 1.260 & 1.260 & 1.127 & 1.218 & 1.291 & 1.291 & 1.345 \\
\hline 2 & 0.175 & 0.889 & 1.032 & 1.016 & 1.000 & 1.120 & 1.160 & 1.080 & 1.060 & 1.080 \\
\hline 3 & 0.257 & 0.871 & 1.129 & 1.257 & 1.257 & 0.976 & 1.024 & 1.061 & 1.110 & 1.134 \\
\hline 4 & 0.302 & 0.873 & 1.079 & NA & NA & 1.000 & 1.059 & 1.157 & 1.275 & 1.294 \\
\hline 5 & 0.200 & 0.960 & 1.340 & 1.460 & 1.460 & 1.058 & 1.058 & 1.135 & 1.192 & 1.173 \\
\hline 6 & 0.306 & 0.919 & 1.081 & 1.145 & 1.194 & 1.022 & 1.022 & 0.989 & 0.957 & 0.946 \\
\hline 7 & 0.190 & 0.508 & 0.524 & 0.683 & 0.968 & 1.038 & 0.736 & 0.604 & 0.755 & 1.075 \\
\hline 8 & 0.250 & 0.828 & 1.063 & 1.078 & 1.063 & 1.111 & 1.159 & 1.175 & 1.159 & 1.159 \\
\hline 9 & 0.297 & 0.828 & 1.109 & 1.203 & 1.234 & 0.964 & 1.000 & 1.024 & 1.083 & 1.083 \\
\hline 10 & 0.239 & 0.775 & 0.901 & 0.958 & 1.028 & 0.778 & 0.736 & 0.833 & 0.917 & 1.014 \\
\hline 11 & 0.328 & 0.828 & 1.047 & 1.172 & 1.188 & 1.102 & 1.153 & 1.203 & 1.203 & 1.203 \\
\hline 12 & 0.219 & 0.890 & 1.055 & 1.110 & 1.137 & 1.000 & 1.047 & 1.035 & 1.035 & 1.035 \\
\hline 14 & 0.270 & 0.841 & 1.079 & 1.190 & 1.190 & 1.000 & 1.013 & 1.013 & 1.064 & 1.077 \\
\hline 15 & 0.256 & 0.722 & 0.944 & 1.022 & 0.989 & 1.048 & 1.060 & 1.036 & 1.060 & 1.036 \\
\hline 16 & 0.157 & 0.725 & 1.078 & 1.196 & 1.216 & 0.907 & 0.889 & 0.926 & 0.981 & 1.000 \\
\hline 17 & 0.136 & 0.364 & 0.727 & 0.750 & NA & 0.790 & 0.774 & 0.790 & 0.806 & NA \\
\hline 18 & 0.200 & 0.857 & 1.143 & 1.229 & 1.229 & 0.917 & 0.917 & 0.958 & 1.014 & 1.014 \\
\hline 19 & 0.155 & 0.759 & 1.034 & 1.121 & 1.138 & 0.889 & 0.907 & 0.963 & 1.074 & 1.093 \\
\hline 20 & 0.231 & 0.892 & 1.123 & 1.185 & 1.200 & 1.060 & 1.045 & 1.119 & 1.134 & 1.134 \\
\hline 21 & 0.246 & 0.831 & 1.031 & 1.046 & 1.108 & 1.051 & 1.038 & 1.051 & 1.038 & 1.077 \\
\hline
\end{tabular}


Table 2. Cont.

\begin{tabular}{|c|c|c|c|c|c|c|c|c|c|c|}
\hline \multirow{2}{*}{ Proband/Time } & \multicolumn{5}{|c|}{ RUL-Flossing Aplication (\%) } & \multicolumn{5}{|c|}{ LUL-without Aplication (\%) } \\
\hline & y_NN & $\mathbf{y}_{-} \mathbf{T} 2$ & y_T5 & $\mathbf{y}_{-} \mathbf{T} 10$ & $\mathbf{y}_{-}$T15 & y_NN & $\mathbf{y}_{-} \mathbf{T} 2$ & y_T5 & $\mathbf{y}_{-} \mathbf{T} 10$ & $\mathrm{y}_{-} \mathrm{T} 15$ \\
\hline 22 & 0.308 & 0.785 & 1.015 & 1.077 & 1.108 & 1.014 & 1.000 & 1.056 & 1.056 & 1.056 \\
\hline 24 & 0.176 & 0.882 & 1.176 & 1.157 & 1.098 & 1.050 & 1.067 & 1.067 & 1.067 & 1.050 \\
\hline 25 & 0.278 & 0.796 & 1.130 & 1.222 & 1.222 & NA & NA & NA & NA & NA \\
\hline 26 & 0.235 & 0.868 & 1.000 & 1.059 & NA & 1.062 & 1.049 & 1.049 & 1.086 & NA \\
\hline 27 & 0.215 & 0.800 & 1.015 & 1.031 & 1.031 & 1.057 & 1.094 & 1.132 & 1.132 & 1.132 \\
\hline Diameter & 0.237 & 0.824 & 1.057 & 1.127 & 1.169 & 1.009 & 1.020 & 1.042 & 1.075 & 1.109 \\
\hline Median & 0.239 & 0.831 & 1.078 & 1.133 & 1.163 & 1.030 & 1.042 & 1.050 & 1.065 & 1.078 \\
\hline $\begin{array}{l}\text { Standard } \\
\text { deviation }\end{array}$ & 0.052 & 0.139 & 0.160 & 0.176 & 0.141 & 0.091 & 0.132 & 0.148 & 0.138 & 0.112 \\
\hline
\end{tabular}




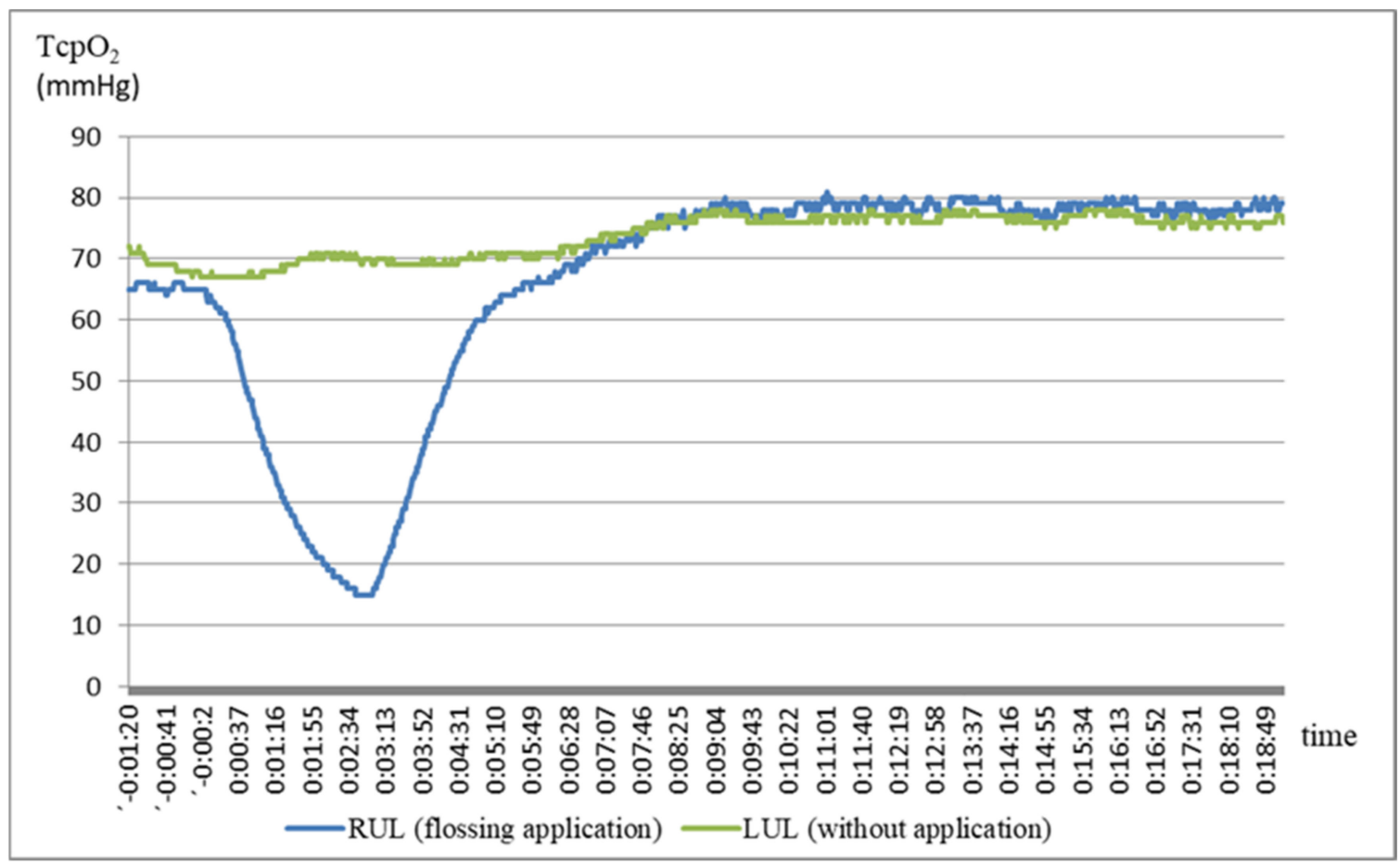

Figure 2. Change in blood flow in one proband (No. 20 in Tables 1 and 2) in the right upper limb (RUL), where flossing was applied, and in the left upper limb (LUL) without application.

As shown in Figure 2, a decrease in blood flow in the right upper limb results in the gradual elevation of blood flow in the left limb. However, this phenomenon is not the rule. In contrast, in some probands, the blood flow to the other limb decreased during the application, as reflected in Table 1.

Figure 3 (boxplot) shows the development of blood flow to both limbs during the application of flossing in all probands. In the case of the right upper limb, we can see a significant perfusion depression. It then normalizes and even exceeds the entry level.

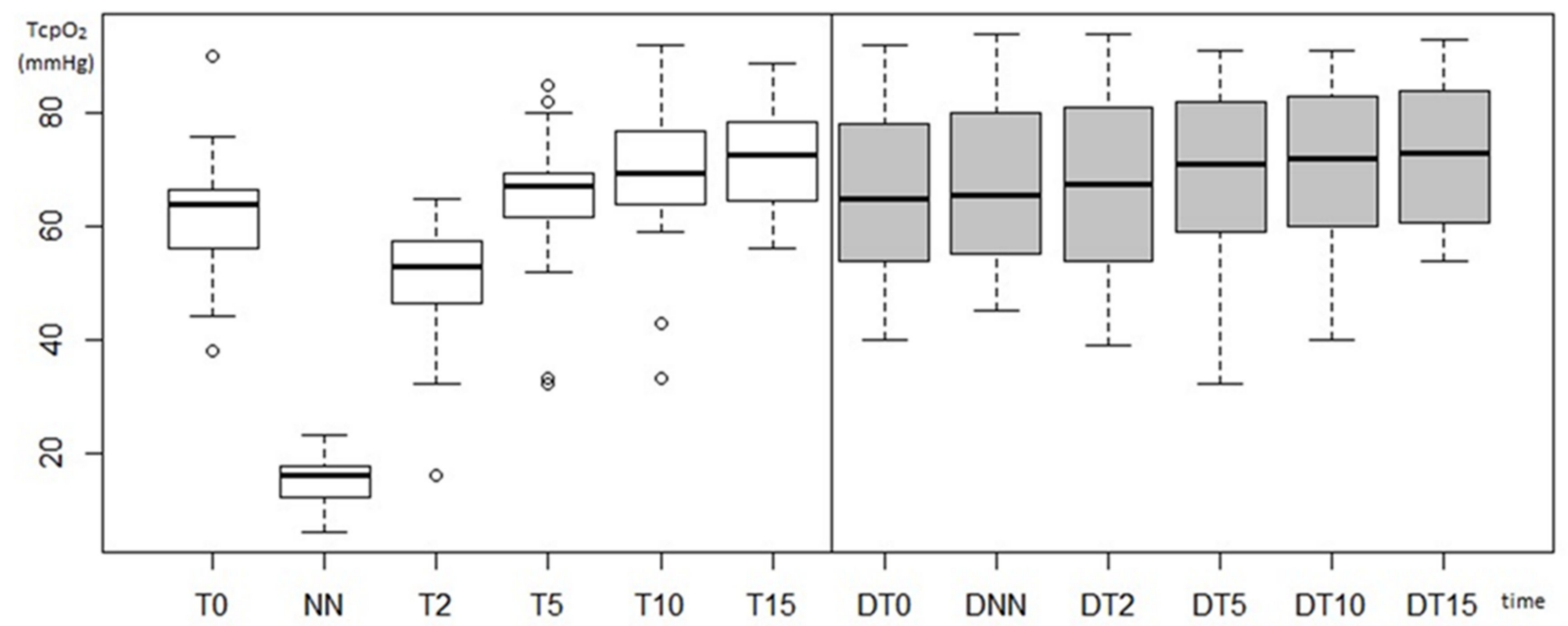

Figure 3. Course of blood flow in the right upper limb, where flossing was applied, and in the left upper limb without application (T0-baseline, NN-lowest value, T2-after $2 \mathrm{~min}$, T5-after $5 \mathrm{~min}$, T10-after $10 \mathrm{~min}$, T15-after 15 min, D-left upper limb without application). 
In the case of the left upper limb, a slight elevation of the median blood flow over time can be noticed. Figure 3 also shows a significant variance of the data. In the right upper limb, the standard deviations take on lower values than in the left limb. Although standard deviations are larger in the left limb, no extreme values were recorded here as in the case of the right upper limb (e.g., input values at $\mathrm{T} 0$ in the range of $46-90 \mathrm{mmHg}$ ).

Subsequently, we observe only the elevation of perfusion in the left upper limb over time.

The measured data depends on the level of input blood flow. To eliminate this dependence, perfusion changes were expressed in relation to the input value $(y=y r / y t 0)$, see Table 2.

Figure 4 shows the change in blood flow over time in relative terms. In this case, standard deviations are significantly lower than in the case of expression using absolute values (Figure 3). Although even here there are extreme values that stand out from the otherwise uniform set.

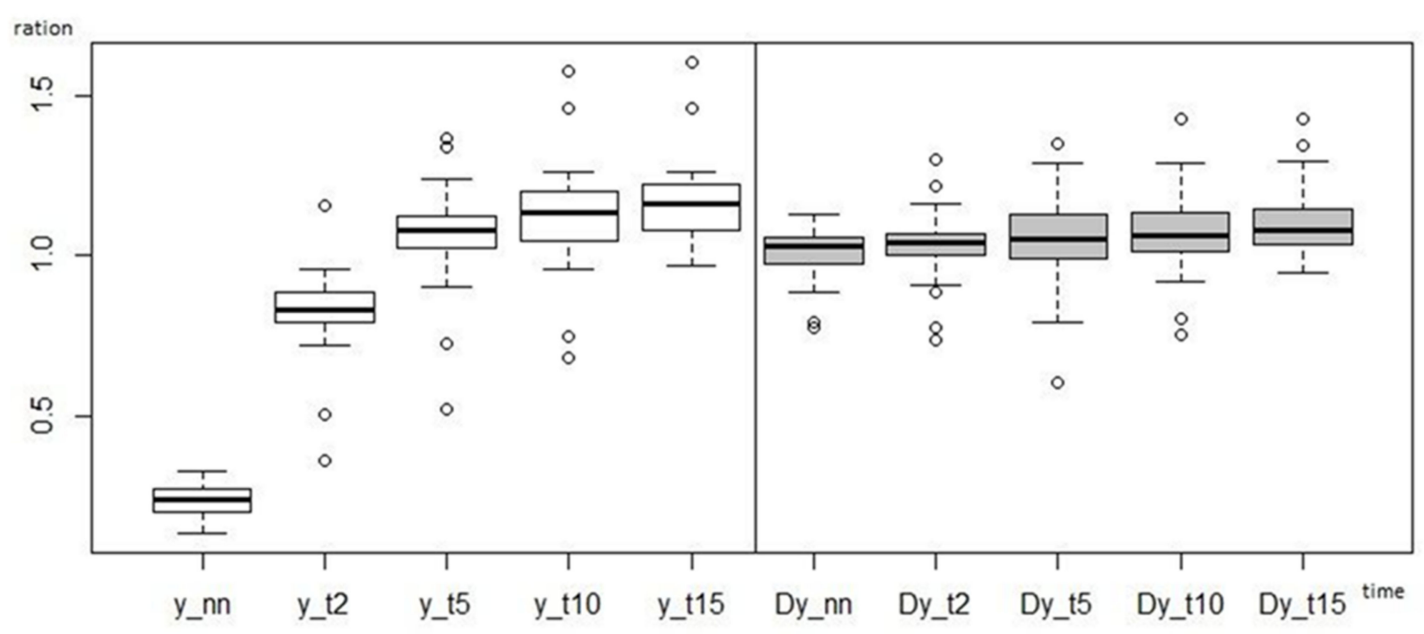

Figure 4. Course of the change in blood flow to the right upper limb, where flossing was applied, and to the left upper limb, where it was not applied, in relative terms (boxplot) (NN-lowest value, T2-after 2 min, T5-after 5 min, T10-after 10 min, T15-after 15 min, D-left upper limb without application).

Figures 2 and 3 and Table 1 show a significant decrease in blood flow to the right upper limb during flossing. After removal of flossing, the perfusion rises again, already 5 min after the moment of the lowest blood flow exceeds the entry level. The maximum is reached at the 15th minute. Probands no. 7 and no. 17, where the perfusion was not adjusted even at the 15th minute from its maximum decrease, deviate from this rule.

Using a linear model, a highly statistically significant change in the blood flow to the right upper limb was found during the entire measurement $(p<2.2 \mathrm{e}-16)$.

After two minutes of application, the blood supply to musculus biceps brachii of the right upper limb decreases to $23.68 \%$ of the original value. Two minutes after reaching the lowest $\mathrm{tcpO}_{2}$ (T2), this is $82.368 \%$ of the original blood supply. After five minutes (T5), tcpO $\mathrm{O}_{2}$ rises by $5.719 \%$ above the entry level. $10 \mathrm{~min}$ (T10) after lowest value (NN), tcpO $\mathrm{O}_{2}$ is $112.68 \%$ and at time T15 $116.889 \%$ of the original value.

In the case of the left upper limb, changes in blood flow are statistically significant only at the NN point and time T15, as confirmed by a linear model.

This basic model can be simplified using the L2 model, where when comparing the two models to test ANOVA, no statistically significant difference was triggered $(p=0.2628)$. (This basic model can be simplified by using Model L2 when comparing both models ANOVA was no statistically significant difference $(p=0.2628)$; lineal model L2: h1: $y$ percent $=c+a 15 \times$ T15).

At the NN RUL (right upper limb) point, there is a statistically significant $(p=0.001)$ increase in LUL (left upper limb) blood flow (by 3.674\%). The subsequent elevation of the 
perfusion does not reach statistical significance up to T15 when it increases to $110.928 \%$ ( $p=0.05$ ) of the original value. (This was confirmed by linear models L1 and L2). During the application of flossing to the area of the shoulder joint on the application side (right upper limb), there is a statistically significant change also in the other side upper limb (left), where flossing was not applied.

In this study, we also focused on comparing the time of depression with the time of the next elevation to the original value. When comparing the mean time of depression (2:58 $\mathrm{min}$ ) with the mean time of elevation $(4: 19 \mathrm{~min})$, it is evident that the subsequent adjustment of perfusion to the original value is slower than its previous decrease. These changes were compared using a paired $t$-test. Paired $t$-test confirmed that the perfusion adjustment time is statistically significantly longer than the depression time at $p=0.02442$. Two probands (no. 7 and no. 17) did not reach the initial perfusion value even after $15 \mathrm{~min}$. These probands, together with proband no. 10, who reached the input value after 10:37 min, contribute to a longer final elevation time. Nevertheless, they were left (out) in the evaluation of the experiment. In case of an unknown perfusion adjustment time, a time of $15 \mathrm{~min}$ was used.

We found that the change in blood flow is highly variable for individual probands. The time required for the blood supply to return to the input value after the end of the flossing application ranges from 1:50 $\mathrm{min}$ to 10:37 $\mathrm{min}$. The average time of elevation of blood flow is 4:19 min (calculated at $15 \mathrm{~min}$ for probands who did not return to the original value). Variability of blood flow adjustment is also reflected in the difference between the mean elevation time and the median value. While the mean time to depression and its median are equal, the median of elevation is 3:08 min., which is by 1:11 min less than the average time.

\section{Discussion}

The aim of our study was to determine the change in the blood supply to the musculus biceps brachii during and after compression therapy applied to the upper limb in the area of the shoulder joint by the flossing method. We noted a significant decrease in blood flow to musculus biceps brachii after flossing to the shoulder joint on the upper limb where flossing was applied, but there was also a statistically significant reduction of blood flow to the original value and a significant increase in blood flow to the opposite limb, i.e., the limb where flossing was not applied.

In the available literature, the effect of flossing is related to the so-called sponge effect. The blood flow, initially markedly inhibited by occlusion, shows a marked increase after its elimination. It even reaches a level exceeding the inlet flow [11]. In our experiment, we expected that in accordance with the above assumption there would be a decrease in blood flow during the application and a subsequent increase in blood flow after the removal of compression. This principle was not confirmed in our experiment because the elevation time was statistically significantly longer than the depression time.

The sponge effect is considered in the available literature as one of the basic effects that bring benefits in the application of flossing. It is assumed that the massive blood circulation, which occurs after reduced blood circulation during the application of flossing, is a key factor in the positive effect of this method. However, these considerations are only speculative, because the blood supply to the tissues when applied by flossing has not been studied so far. Our study is the first study to evaluate muscle blood flow during flossing, and our results showed a discrepancy between the expected effect and the actual effect. Future research should therefore focus more on the analysis of the physiological mechanisms of the flossing method, as it is still difficult to determine these mechanisms from the available literature. Our evaluation was performed on the biceps brachii muscle and therefore it will also be appropriate in the future for a similar evaluation to be performed on other muscles.

We recorded a decrease in perfusion after two minutes of flossing application to $6.23 \mathrm{mmHg}$, which corresponds to an average of $23.47 \%$. This may appear to be a dramatic 
decrease, as some studies [26] report $30 \mathrm{mmHg}$ perfusion as a criterion for surgery in the ischemic disease of lower extremities (IDLE) or diabetes mellitus (DM). TcpO $\mathrm{O}_{2}$ of $10 \mathrm{mmHg}$ at rest is considered generally very critical. In contrast, Prill [10] found the perfusion $<30 \mathrm{mmHg}$ even in healthy individuals. However, we must take into account that the studies above dealt mainly with long-term adverse conditions. In our case, it is significant tissue hypoxia but a very short-lived one. Even so, it is necessary to consider that due to the significant depression of perfusion after only two minutes of flossing tissue damage could occur, and results obtained by us correspond to the recommended application time, which is currently recommended at the length of $2 \mathrm{~min}$. In view of the above, great caution is required when performing the flossing method, and the application time of $2 \mathrm{~min}$ appears to be marginal.

An interesting finding was the relationship in blood supply to the right and left upper limbs, respectively, musculus biceps brachii on the arm where flossing was applied and on the side where it was not applied.

On the upper limb, where flossing was applied, the values acquire statistically very significant changes. There will be a decrease in blood flow to $23.47 \%$ with subsequent elevation above the original level. While in the second minute the blood flow is $82 \%$, in the fifth minute it already exceeds the input level and further rises to $116.88 \%$ at the end of the experiment. Blood flow to the upper limb, where flossing was not applied, is somewhat different. At the time of the lowest blood supply on the side of the performed application, we note a statistically significant increase in perfusion (by 3.674\%) of the contralateral limb, i.e., limb without application.

Subsequently, the blood supply on the side without application increases slightly until the 15 th minute, when it reaches $110.96 \%$. Only this is a statistically significant change in perfusion. We explain the described phenomena, for example, due to the redistribution of blood during the application and after removal of flossing, which may also be due to an increase in cardiac output.

Despite the fact that the study brought a number of new findings, we are aware of certain limits. These involve a relatively low number of probands-the monitored sample consisted of 27 probands, followed by the fact that flossing was applied to the shoulder joint; blood flow was measured in musculus biceps brachii, and therefore conclusions of this study can be related only to this area. Whether similar principles apply to an application of this method to other parts of the human body, how the blood flow at the site of loading of the tape, and further distal changes should be the subject for further investigation. Anthropometric criteria have not been established for the selection of probands. Although we did not notice any significant differences in these indicators in the group of our probands, we are aware that anthropometric characteristics may be another limiting factor in our results.

\section{Conclusions}

The study showed significant changes in blood flow to the biceps brachii muscle, which do not correspond to the generally declared changes (sponge effect) in blood flow when using flossing. After a 2 min application of flossing, there is a massive decrease in blood flow, and after the compression is removed, there is a gradual, slow increase in blood flow on the limb, where the application was performed.

Due to the significant depression of perfusion after only two minutes of flossing a great caution is required when performing the flossing method, and the application time of 2 min appears to be marginal.

The presented study helped to clarify some of the modes that are assumed in the application of the flossing method and can be seen as one of the first studies trying to objectivize the procedure. However, it is necessary that the results presented by us are followed by further studies that would contribute to elucidating the modes of action in the widely used flossing approach also on other parts of the body. 
Author Contributions: Conceptualization, D.P. (Dagmar Pavlů) and D.P. (David Pánek); methodology, D.P. (Dagmar Pavlů) and D.P. (David Pánek); validation, D.P. (Dagmar Pavlů), D.P. (David Pánek) and E.K.; formal analysis, D.P. (Dagmar Pavlů), D.P. (David Pánek) and E.K.; investigation, E.K., D.P. (David Pánek) and D.P. (Dagmar Pavlů); resources, D.P. (David Pánek) and D.P. (Dagmar Pavlů); data curation, E.K.; writing-original draft preparation, D.P. (Dagmar Pavlů) and E.K.; writing-review and editing, D.P. (Dagmar Pavlı̊) and J.S.T.; supervision, D.P. (David Pánek) and J.S.T.; project administration, D.P. (Dagmar Pavlů). All authors have read and agreed to the published version of the manuscript.

Funding: This research received no external funding.

Institutional Review Board Statement: Ethics Committee of Charles University, Faculty of Physical Education and Sport (EK UK FTVS No. 224/2018).

Informed Consent Statement: Informed consent was obtained from all subjects involved in the study.

Data Availability Statement: The datasets generated for this study are available on request to the corresponding author.

Acknowledgments: Authors express their gratitude to all participants of the study.

Conflicts of Interest: The authors declare no conflict of interest.

\section{References}

1. Navrátilová, Z. Compression therapy in venous diseases (in Czech Kompresivní terapie u žilních onemocnění). Interní Med. Pro Praxi. 2008, 10, 449-455, ISSN 1212-7299.

2. Kruse, S. Easy Flossing, 1st ed.; Georg Thieme Verlag kg: Stuttgart, Germany, 2018; ISBN 978-3-13240830-2.

3. Navrátilová, Z. Compression therapy of venous and venolymphatic insufficiency (in Czech Kompresivní terapie venózní a venolymfatické insuficience). Ref. Výběr Dermatovenerol. 2012, 54, 60-64, ISSN 1213-9106.

4. Hrubá, V.; Nakládalová, M.; Smolková, P. Vacuum-compression therapy from the nurse's point of view (in Czech). In Proceedings of the Conference XXX Kongres Pracovního Lékařství s Mezinárodní Účastí, Prague, Czech Republic, 13-14 October 2011; p. 31, ISBN 978-80-7071-319-8.

5. Raguzzoni, M.; Campa, F.; Servadei, S.; Coortesi, M.; Gatta, G.; Piras, A. ARENA Compression. Kann Kompressionsbekleidung im Schwimmsport zur schnelleren Regeneration (nach dem Wettkampf) beitragen? 2015. Available online: https://www. arenawaterinstinct.com/de_de/powerskin-compression/article/ (accessed on 24 November 2019).

6. Staaret, K.; Cordoza, G. Becoming a Supple Leopard: The Ultimate Guide to Resolving Pain, Preventing Injury, and Optimizing Athletic Performance; Victory Belt Publishing: Las Vegas, NV, USA, 2013; ISBN 1936608588.

7. Kage, V.; Gurav, G. Effect of neural flossing technique on pain, cervical range of motion and functional ability in subjects with acute, sub-acute trapezitis: An experimental study. Int. J. Appl. Res. 2017, 3, 818-822.

8. Bowen, M.D. Flossing or Alternative Interdental Aids? J. Dent. Hyg. 2012, 86, 58-62. [PubMed]

9. Kiefer, B.N.; Lemarr, K.E.; Enriquez, C.H.C.; Tivener, K.A.; Daniel, T. Pilot Study: Perceptual Effects of the Voodoo Floss Band on Glenohumeral Flexibility. Int. J. Athl. Ther. Train. 2017, 22, 1-16. [CrossRef]

10. Prill, R.; Schulz, R.; Michel, S. Tissue flossing: A new short-duration compression therapy for reducing exercise-induced delayedonset muscle soreness. A randomized, Control. and double-blind pilot cross-over trial. J. Sports Med. Phys. Fit. 2019, $59,5-861$. [CrossRef] [PubMed]

11. Ahlhorn, A.; Krämer, D. Flossing in Therapie und Training; Riva: München, Germany, 2016; ISBN 978-3-86883-912-8.

12. Williams, Z.; Carlson, S.; Rife, G. Comparing the Effects of Tissue Flossing and Instrument Assisted Soft Tissue Mobilization on Ankle Dorsiflexion. In Proceedings of the The Research and Scholarship Symposium, Cedarville, OH, USA, 3 April 2019.

13. Plocker, D.; Wahlquist, B.; Dittrich, B. Effects of tissue flossing on upper extremity range of motion and power. Int. J. Exerc. Sci. Conf. Proc. 2015, 12, 37.

14. Hodeaux, K. Effect of Floss Bands on Elbow Range of Motion in Tennis Players. Master's Thesis, University of Arkansas, Fayetteville, NC, USA, 2017; p. 27.

15. Driller, M.W.; Overmayer, R.G. The effects of tissue flossing on ankle range of motion and jump performance. Phys. Ther. Sport 2017, 25, 20-24. [CrossRef] [PubMed]

16. Driller, M.K.; Mackay, K.; Mills, B.; Tavarese, F. Tissue flossing on ankle range of motion, jump and sprint performance: A follow-up study. Phys. Ther. Sport. 2017, 28, 29-33. [CrossRef] [PubMed]

17. Mills, B.; Mayo, B.; Tavares, F.; Driller, M. The Effect of Tissue Flossing on Ankle Range of Motion, Jump, and Sprint Performance in Elite Rugby Union Athletes. J. Sport Rehabil. 2019, 28, 282-286. [CrossRef] [PubMed]

18. Vogrin, M.; Kalc, M.; Ličen, T. Acute Effects of Tissue Flossing Around the Upper Thigh on Neuromuscular Performance: A Study Using Different Degrees of Wrapping Pressure. J. Sport Rehabil. 2020, 25, 1-8. [CrossRef] [PubMed] 
19. Konrad, A.; Bernsteiner, D.; Budini, F.; Reiner, M.M.; Glashüttner, C.H.; Berger, C.; Tilp, M. Tissue flossing of the thigh increases isometric strength acutely but has no effects on flexibility or jump height. Eur. J. Sport Sci. 2020, 14, 1-11. [CrossRef] [PubMed]

20. Kaneda, H.; Takahira, N.; Tsuda, K.; Tozaki, K.; Kudo, S.; Takahashi, Y.; Sasaki, S.; Kenmoku, T. Effects of Tissue Flossing and Dynamic Stretching on Hamstring Muscles Function. J. Sports Sci. Med. 2020, 19, 681-689. [PubMed]

21. Bohlen, J.; Arsenault, M.; Deane, B.; Miller, P.; Guadagno, M.; Dobrosielski, D.A. Effects of applying floss bands on regional blood flow. Int. J. Exerc. Sci. Conf. Proc. 2014, 9, 7.

22. Kreutzer, R.; Stechmann, K.; Eggers, H.; Kolster, B.C. Flossing: Wirksame Hilfe Bei Scherzen und Verletzungen; Effektive Übungen zum Muskelaufbau, 1st ed.; KVD-Der Medzinverlag: Berlin, Germany, 2016; ISBN 978-3-86867-316-6.

23. Bém, R.; Jirkovská, A.; Dubský, M.; Fejfarová, V.; Wosková, V.; Fexová, P. Long-term experience with transcutaneous oximetry (in Czech: Dlouhodobé zkušenosti s transkutánní oxymetrií). Bull. HPB Odb. Probl. Obl. Diagn. Léčby Chir. Onemocnění Jater. Žlučových Slinivky 2008, 16, 75-80, ISSN 1210-6755.

24. Précise 8008 Gen.2: The Practical Complete System. Medicap GmHb: For a Quick and Precise Transcutaneous Measurement of Partial Pressure of Oxygen—tcpO2/TCOM. Available online: https://www.medicap.de/english/homecare-products/new-pr\% C3\%A9cise-8008-gen-tcpo2/ (accessed on 4 December 2019).

25. Ruben, D.R.; Hirst, K.R.; Wittnebel, L.; Wettstein, R. AARC Clinical Practice Guideline: Transcutaneous Monitoring of Carbon Dioxide and Oxygen. Respir. Care 2012, 57, 1955-1962. [CrossRef]

26. Ston, R.J.; Šilhová, E. Transcutaneous oximetry and diabetic foot. (in Czech Transkutánní oxymetrie a diabetická noha). Med Trib. 2011, 7, D2, ISSN 1214-8911. 